Short Communication

\title{
Interplay among regulators of multidrug resistance in Kluyveromyces lactis
}

\author{
Zuzana Hodurova, Nora Toth-Hervay, Zuzana Balazfyova and Yvetta Gbelska \\ Department of Microbiology and Virology, Faculty of Natural Sciences, Comenius University, Mlynska dolina B-2, 84215 \\ Bratislava, Slovak Republic
}

\begin{abstract}
The KlYAP1 and KlPDR1 genes encode two main transcriptional regulators involved in the control of multidrug resistance in Kluyveromyces lactis. Deletion of KlPDR1 or KlYAP1 genes in K. lactis generated strain hypersusceptible to diamide, benomyl, fluconazole and oligomycin. Overexpression of genes KlPDR1 or KlYAP1 from a multicopy plasmid in the Klpdr1 1 mutant strain increased the tolerance of transformants to all the drugs tested. YRE response elements were found in the promoter of the KlPDR1 gene. Gel retardation assays confirmed the binding of KlYaplp to the YREs in the KlPDR1 gene promoter indicating that KlYaplp can control the KlPDR1 gene expression.
\end{abstract}

Key words: Multidrug resistance - Oxidative stress - Transcriptional regulators - Kluyveromyces lactis

\begin{abstract}
Abbreviations: MDR, multiple-drug resistance; MFS, major facilitator superfamily; PDR, pleiotropicdrug resistance; YAP, yeast AP-1-like; YNB medium, yeast nitrogen base medium; YPD medium, yeast extract/peptone/dextrose medium; YRE, yeast AP-1-like recognition element.
\end{abstract}

The cellular stress response is evolutionary conserved in all living organisms, a major role being attributed to the molecular mechanisms that confer stress protection. One of such mechanisms elicited by the cells in the presence of unrelated chemicals is referred to as multidrug resistance (MDR). The ability of cells to tolerate multiple-different drugs is a major concern for human health, as it leads to antibiotic resistance in pathogens and enables cancer cells to survive chemotherapy (Kane et al. 1990). MDR in eukaryotes often result from changes in expression of membrane transport systems (Ling 1997). The MDR regulatory pathway has been extensively studied in the model yeast Saccharomyces cerevisiae. The expression of the transporter encoding genes involved in MDR is under the control of two regulatory networks: pleiotropic drug resistance (PDR) and yeast $\mathrm{AP}$ 1-like (YAP). They include specific transcriptional regulatory proteins containing zinc cluster (typically exhibiting

Correspondence to: Yvetta Gbelska, Department of Microbiology and Virology, Faculty of Natural Sciences, Comenius University, 84215 Bratislava, Slovak Republic

E-mail: gbelska@fns.uniba.sk a $\mathrm{Zn}(\mathrm{II})_{2} \mathrm{Cys}_{6}$ type of zinc finger) and basic region-leucine zipper (bZip)-sequence.

The PDR network in S. cerevisiae comprises 10 transcription factors regulating about 70 different target genes (Moye-Rowley 2003a; Fardeau et al. 2007). In this network, the Pdr1p transcription factor has the largest set of potential targets (about 50). Pdr1p and its functional homologue, Pdr3p, were identified as regulators of the basal level of drug resistance in yeast cells (Balzi et al. 1987; Delaveau et al. 1994). Gain- or loss-of-function alleles of PDR1 and $P D R 3$ confer resistance or sensitivity to a large spectrum of unrelated drugs, through constitutive modifications to the expression of ATP binding cassette transporters, major facilitator superfamily (MSF) members or enzymes modifying the lipid composition of the plasma membrane (Kolaczkowska and Goffeau 1999). Although PDR1 and PDR3 display some functional redundancy they seemed to have quantitatively different contributions to drug resistance (Delaveau et al. 1994; Katzmann et al. 1994). Pdr1p and Pdr3p recognize the same DNA consensus motif (PDRE - pleiotropic drug response element) found upstream of most genes regulated by these transcription factors (Katzmann et al. 1994; Dela- 
hodde et al. 1995). Putative orthologs of PDR1 and PDR3 genes were identified also in genomes of other sequenced hemiascomytes yeast species (Dujon et al. 2004). In species that diverged before the occurence of the ancestral whole genome duplication, such as Kluyveromyces lactis, only one ortholog has been identified (Bussereau et al. 2006; Balkova et al. 2009).

The YAP network contains 8 members involved in the oxidative stress response and drug resistance regulation in S. cerevisiae (Rodrigues-Pousada et al. 2004). The YAP1 gene encodes a 650 amino acid transcription factor that was initially isolated as a biochemical homologue of mammalian AP-1 (Harshman et al. 1988). Yap1p contains an amino-terminally located basic region-leucine zipper type of DNA-binding domain and has been extensively studied in regards to its role in oxidative stress tolerance. Yap1p binds to Yap1 recognition elements (YRE) TTA(C/G)T(A/ $\mathrm{C}) \mathrm{A}$, located in the promoters of its target genes (Nguyen et al. 2001) and controls the expression of genes encoding the majority of antioxidants and thiol-oxidoreductases, such as the glutathione reductase GLR1 and the thioredoxin reductase TRR1 (Moye-Rowley 2003b; Herrero et al. 2008). Yap1p is also essential for the cell's response to cadmium or drug exposures and can be activated by chemicals (e.g. diamide) or antifungal agents (e.g. benomyl) (Lucau-Danila et al. 2005). Upon changes in cellular redox status, Yap1p is rapidly recruited to the nucleus, where it activates the genes involved in cellular antioxidant defences and thiol redox control (Delaunay et al. 2002; Azevedo et al. 2003; Rodrigues-Poussada et al. 2004). Recently, the Yaplp ortholog in K. lactis has been characterized and shown to be involved in oxidative stress response (Billard et al. 1997). In the present work we studied the role of KlYap1p in the control of $K$. lactis MDR.

Experiments were performed using the following strains: K. lactis PM6-7A (MATa uraA1 ade2 $\mathrm{Rag}^{+} \mathrm{pKD1}$ ) and MW

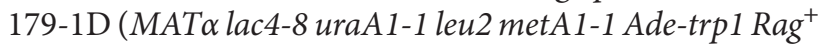
pKD1) (Chen et al. 1992) as well as PM6-7A/pdr1 (Balkova et al. 2009) and MW 179-1D/yap1s (Billard et al. 1997). Yeast strains were grown in YPD medium (in \%: glucose 2, bactopeptone 1 , yeast extract 1 ) or in YNB minimal medium containing $0.67 \%$ yeast nitrogen base without amino acids, $2 \%$ glucose and appropriate nutritional requirements. The media were solidified with $2 \%$ bactoagar. The KlPDR 1 and KlYAP1 genes (Imrichova et al. 2005; Balkova et al. 2009) were cloned in multicopy plasmid pRS306K (2 $\mu \mathrm{m} U R A 3$ ARS1 KARS2 ori Amp ${ }^{r}$ ) (Heus et al. 1994) under the control of their own promoter. Yeast cells were transformed by electroporation (Thompson et al. 1998).

The Escherichia coli XL1-Blue strain was used as a host for plasmid constructions and propagation. The bacterial cells were grown at $37^{\circ} \mathrm{C}$ in Luria-Bertani medium (in \%: tryptone $1, \mathrm{NaCl} 1$, yeast extract $0.5 ; \mathrm{pH} 7.0$ ) supplemented with $100 \mu \mathrm{g} / \mathrm{ml}$ ampicillin for selection of transformants.

Sensitivities of yeast cells to drugs were determined by spot assay. Yeast strains were grown in liquid medium to the early stationary phase $\left(5 \times 10^{7}\right.$ cells per $\left.\mathrm{ml}\right)$. Serial dilutions (10-fold) of each strain were spotted onto solid minimal medium supplemented with various concentrations of the specific drug being tested. Qualitative growth differences among transformants were recorded

Table 1. Kluyveromyces lactis orthologues containing predicted YRE

\begin{tabular}{|c|c|c|c|}
\hline ORF & Location relative to ATG & Matching sequence & Gene product role \\
\hline \multirow{2}{*}{ KLLA0A09119g } & -392 to -386 & gttTTTGTAAaat & \multirow{2}{*}{ KlPDR1 (transcription factor) } \\
\hline & -289 to -283 & aaaTTACAAAgcc & \\
\hline \multirow{2}{*}{ KLLA0C18931g } & -454 to -448 & acaTTAGTAAtga & \multirow{2}{*}{ KNQ1 (MFS transporter) } \\
\hline & -721 to -715 & gcgTTACTCActc & \\
\hline \multirow{2}{*}{ KLLA0B09702g } & -890 to -884 & accTTACTCAtcc & \multirow{2}{*}{$\begin{array}{l}\text { Similar to } S . \text { cerevisiae PDR } 12 \\
\text { (ABC MDR transporter) }\end{array}$} \\
\hline & -648 to -642 & cggTTAGTCAggt & \\
\hline KLLA0F18106g & -681 to -675 & aaaTTAGTAAtat & $\begin{array}{l}\text { Similar to } \text { S. cerevisiae TPO1 } \\
\text { (polyamine transporter) }\end{array}$ \\
\hline \multirow{2}{*}{ KLLA0E00462g } & -791 to -785 & tgaTTAGTAAaat & \multirow{2}{*}{$\begin{array}{l}\text { Similar to } S \text {. cerevisiae YBT1 } \\
\text { (yeast bile transporter) }\end{array}$} \\
\hline & -600 to -594 & tagTTTGTAAcgc & \\
\hline KLLA0D19668g & -341 to -335 & gaaTTTGTAAgag & $\begin{array}{l}\text { Similar to S. cerevisiae PDR16 } \\
\text { (protein involved in lipid } \\
\text { biosynthesis and MDR) }\end{array}$ \\
\hline KLLA0C04103g & -52 to -46 & aaaTTAGTAAttg & $\begin{array}{l}\text { Similar to S. cerevisiae RPN4 } \\
\text { (transcription factor, stimulates } \\
\text { expression of proteasome genes) }\end{array}$ \\
\hline
\end{tabular}




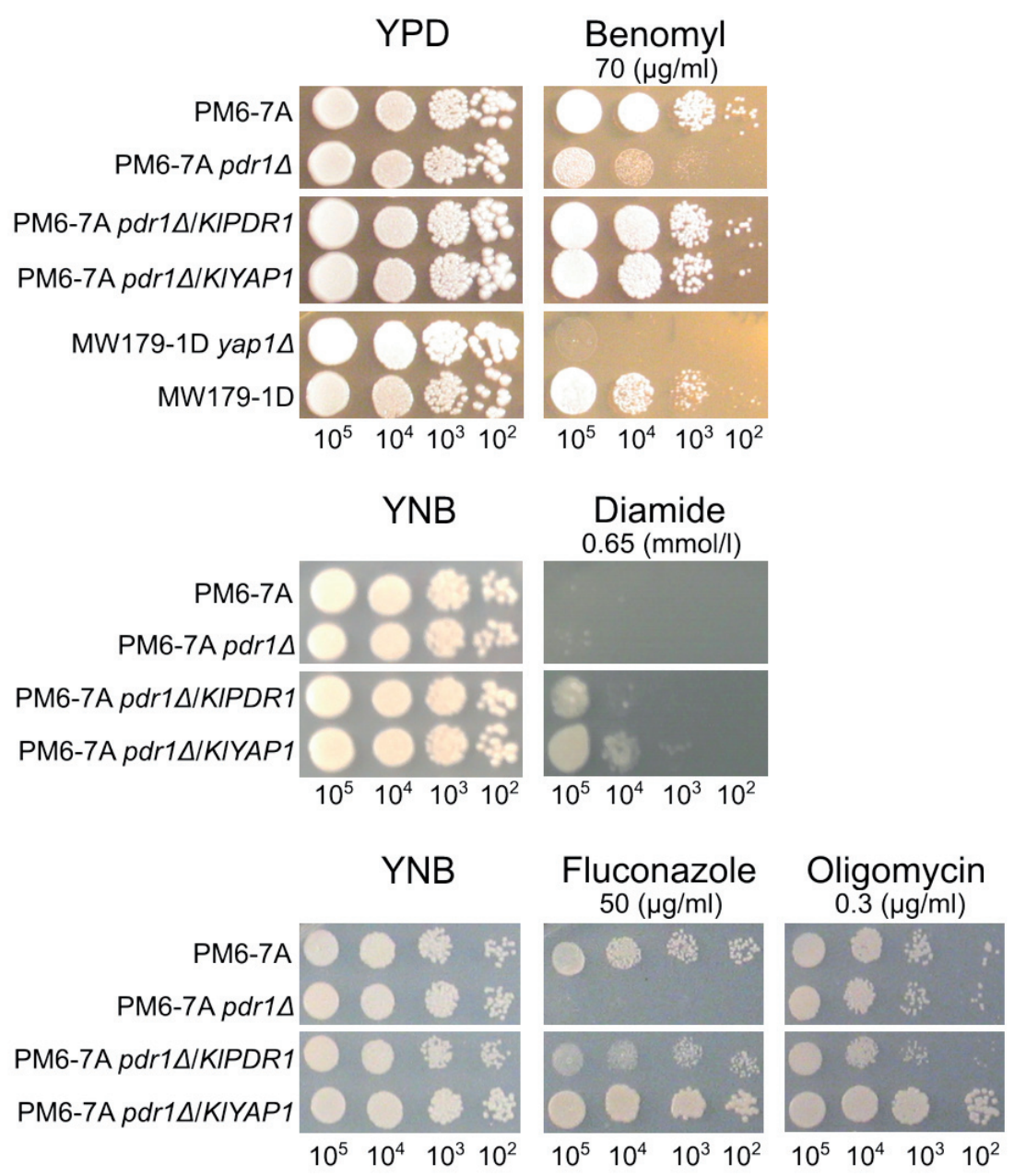

Figure 1. Drug susceptibility testing of K. lactis strains. Spotting assays were performed with serial dilutions of overnight cultures onto YPD (yeast-extract peptone dextrose) or YNB (yeast nitrogen base) minimal medium containing different drugs as indicated. Plates were incubated for 3 (YPD) or 5 (YNB) days at $28^{\circ} \mathrm{C}$.

following the incubation of the plates at $28^{\circ} \mathrm{C}$ from three up to five days.

Formation of the KlYaplp-DNA complex in the protein-DNA binding assay was assayed by a gel retardation procedure according to Imrichova et al. (2005). The double stranded HindII-HindIII DNA fragment of 511 bp from KlPDR 1 promoter was labelled with ${ }^{32} \mathrm{P}$ and incubated with cell extracts (see below) in $20 \mu \mathrm{l}$ of incubation buffer (in mmol/l: 20 Tris-Cl (pH 8.0), $5 \mathrm{MgCl}_{2}, 5 \mathrm{CaCl}_{2}, 90 \mathrm{KCl}$, 0.5 dithiothreitol, $1 \mathrm{Na}_{2}$ EDTA, $7.5 \%$ glycerol and $2 \mu \mathrm{g}$ of denaturated salmon sperm DNA as a nonspecific competitor). Binding reactions were carried out at $4^{\circ} \mathrm{C}$ for $15 \mathrm{~min}$ and the reaction mixtures were loaded onto a $4 \%$ polyacrylamide gel in $0.5 \times$ TBE buffer, $\mathrm{pH} 8.3$ (in mmol/l: 45 Tris base, $45 \mathrm{H}_{3} \mathrm{BO}_{3}, 1.2$ EDTA, 2\% glycerol). After electrophoresis at $4^{\circ} \mathrm{C}$, the gel was transferred to the surface of Whatman
3MM paper, dried and visualized by autoradiography. The cell extracts were prepared as follows: The yeast cells were grown in liquid minimal medium containing $2 \%$ glucose as carbon source. After the culture had reached the density of $2 \times 10^{7}$ cells per $\mathrm{ml}$, cells were harvested by centrifugation and washed with extraction buffer (in mmol/l: 0.2 Tris-Cl (pH 8.0), $0.4\left(\mathrm{NH}_{4}\right)_{2} \mathrm{SO}_{4}, 10 \mathrm{MgCl}_{2}, 1 \mathrm{Na}_{2}$ EDTA, $7 \beta$-mercaptoethanol, 1 phenylmethylsulfonyl fluoride (PMFS), $1 \mu \mathrm{g} / \mathrm{ml}$ pepstatin A, $10 \%$ glycerol). The cells suspended in the extraction buffer ( $1 \mathrm{ml}$ for $1 \mathrm{~g}$ cells) were disrupted using ice-chilled, acid washed glass beads ( $0.45 \mathrm{~mm}$ in diameter). The broken cells were centrifuged for $30 \mathrm{~min}$ at $27000 \times \mathrm{g}$, and the supernatant fraction was collected and stored at $-80^{\circ} \mathrm{C}$ until use.

The present work is focused on the role of the transcription regulators KlPdrlp and KlYaplp in K. lactis MDR. 
Computer assisted analysis of the KlPDR1 gene promoter region identified two potential YREs at positions -283 and -386 , respectively (Tab. 1). The presence of Yap $1 p$ recognition elements in the promoter of KlPDR1 suggests a direct interaction of KlYaplp with this promoter. Yaplp is already known as an essential factor in the response to oxidative stress (Moye-Rowley 2003b; Rodrigues-Pousada et al. 2004). Yap 1p confers azole resistance in S. cerevisiae by activating expression of MFS proteins encoded by the ScFLR1 and ScATR1 genes (Kanazawa et al. 1988; Coleman et al. 1997). We have previously demonstrated that the KNQ1 gene, the structural and functional ortholog of the ScATR1 gene encoding a multidrug transporter of the MFS in K. lactis, is a transcription target of KlYaplp (Takacova et al. 2004). The $\mathrm{H}_{2} \mathrm{O}_{2}$ and diamide-induced transcriptional activation of KNQ1 is fully dependent on KlYap1p (Imrichova et al. 2005). As Fig. 1 shows, not only Klyap1 $1 \Delta$ but also Klpdr1s mutant cells were sensitive to diamide and benomyl. On the other hand transformation of a drug sensitive Klpdr1 $1 \Delta$ mutant strain which a plasmidborne KlPDR 1 or KlYAP1 genes, orthologos of which overexpress MDR transport genes in S. cerevisiae (deRisi et al. 2000), resulted in the tolerance of transformants to both drugs (Fig. 1). Although structurally unrelated,

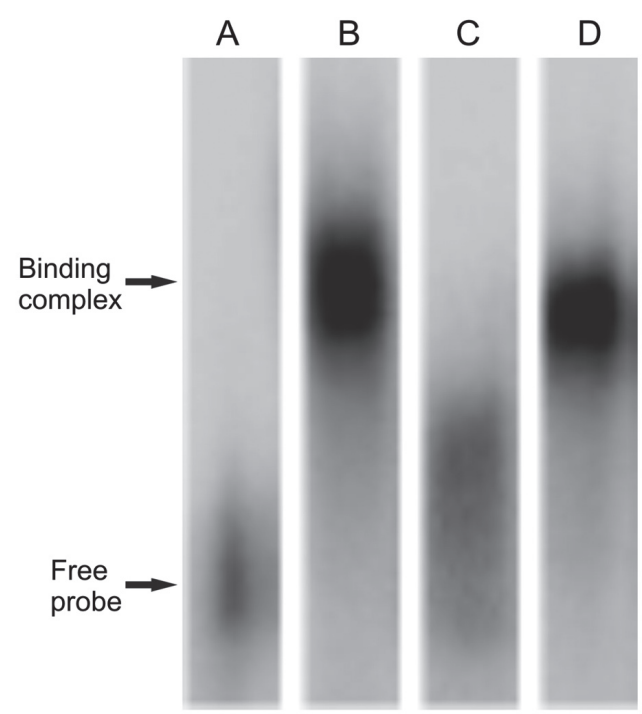

Figure 2. Binding of KlYap1p to the KlPDR 1 gene promoter. ${ }^{32} \mathrm{P}$ labelled DNA probe overlapping both YREs was incubated with 30 $\mu \mathrm{g}$ of protein extracts prepared from strains MW197-1D(YAP1)

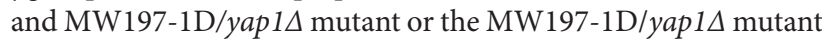
transformed with multicopy plasmid containing KlYAP1. The resulting complexes were resolved by electrophoresis on $4 \%$ nondenaturating polyacrylamide gels. A. Free DNA (without protein extract). B. MW197-1D(YAP1)-wild type. C. MW197-1D/yap1A. D. MW197-1D/yap1A + KlYAP1. both diamide and benomyl have thiol reactive properties (Azevedo et al. 2003) and so they might similarly activate Yap1p through the chemical modification of its C-terminal cysteines (Azevedo et al. 2003). Deletion of KlPDR1 encoding the key transcription factor involved in K. lactis MDR resulted in an increased sensitivity not only to diamide and benomyl, but also to fluconazole and oligomycin. Transformants of the Klpdr1 $\Delta$ mutant cells carrying the KlPDR 1 or KlYAP1 genes on multicopy plasmids exhibited increased ability to tolerate the drugs tested. These results indicate that some of the target genes activated by KlPdr $1 \mathrm{p}$ and/or KlYap1p transcription factors can participate in a process leading to a decreased intracellular level of the drugs in the K. lactis transformants. KlYap1p can alleviate the KlPdr1p deficiency and restore the normal level of $K$. lactis cell's tolerance to the tested compounds. Based on the presence of YREs in the promoter region of KlPDR 1 gene we tried to demonstrate the direct binding of KlYaplp to the KlPDR1 promoter.

We performed an electrophoretic mobility shift assay with a ${ }^{32} \mathrm{P}$ labelled probe $(511 \mathrm{bp})$ derived from the KlPDR1 promoter overlapping the two putative YREs and protein extracts prepared from strains expressing the wild-type level of KlYaplp or containing deletion in the KlYAP1 gene (Klyap1D). The presence of KlYap1p in the protein-DNA complex was demonstrated as follows: First, the complex was absent when protein extracts prepared from the Klyap1 $1 \Delta$ strain were used (Fig. 2, lane C). Second, KlYap1p overexpression from a multicopy plasmid in the Klyap1 $\Delta$ strain led to the appearance of a slowly-migrating complex (Fig. 2, lane D) that also appeared in the presence of protein extracts prepared from the wild-type strain (Fig. 2, lane B). The results suggest that the motifs identified by promoter analysis of the KlPDR1 gene are important for KlYap1p binding in vitro and could indicate a close cooperation of KlPdr1p and KlYaplp in K. lactis.

Finally, we looked for the presence of YRE elements in the promoters of the all $K$. lactis genes. We found at least 150 different KlYap1p target genes. Along with the genes encoding the antioxidants and thiol-oxidoreductases, such as thioredoxin reductase TRR1 ortholog (KLLAF15037g), we found the genes potentially involved in K. lactis MDR (Tab. 1) and more than 100 genes of unknown function.

In summary, this work describes novel regulatory association between transcriptional regulators in K. lactis. The association is presumably direct as suggested by the occurrence of putative KlYaplp transcription factor binding sites in the promoter region of KlPDR 1 gene. KlYap $1 p$ has been shown to drive elevated levels of transcription of KlPDR 1 as measured by use of a KlPDR1-lacZ reporter gene in $S$. cerevisiae (data not shown). We propose that KlYap1p, as a global regulator involves recruiting other zinc-cluster protein to fine-tune the regulation of MDR 
genes in this aerobic, biotechnologically important yeast species.

Acknowledgements. This work was supported by grants from the Slovak Grant Agency of Science (VEGA 1/0078/08), the Slovak Research and Developmental Agency (VVCE-0064-07) and Comenius University (UK/74/2010). Z. H., N. T.-H. Z. B. and Y. G. have no conflict of interest and no financial interest in the publication of this manuscript.

\section{References}

Azevedo D., Tacnet F., Delaunay A., Rodrigues-Pousada C., Toledano M. B. (2003): Two redox centers within Yap1 for $\mathrm{H} 2 \mathrm{O} 2$ and thiol-reactive chemicals signaling. Proc. Radic. Biol. Med. 35, 889-900 doi:10.1016/S0891-5849(03)00434-9

Balkova K., Sarinova M., Hodurova Z., Goffrini P., Gbelska Y. (2009): Functional analysis of the Kluyveromyces lactis PDR1 gene. FEMS Yeast Res. 9, 321-327 doi:10.1111/j.1567-1364.2008.00479.x

Balzi E., Chen W., Ulaszewski S., Capieaux E., Goffeau A. (1987): The multidrug resistance gene PDR1 from Saccharomyces cerevisiae. J. Biol. Chem. 262, 16871-16879

Billard P., Dumond H., Bolotin-Fukuhara M. (1997): Characterization of an AP1-like transcription factor that mediates an oxidative stress response in Kluyveromyces lactis. Mol. Gen. Genet. 257, 62-70 doi:10.1007/s004380050624

Bussereau F., Casaregola S., Lafay J. F., Bolotin-Fukuhara M. (2006): The Kluyveromyces lactis repertoire of transcriptional regulators. FEMS Yeast Res. 6, 325-335 doi:10.1111/j.1567-1364.2006.00028.x

Chen X. J., Wesolowski-Louvel M., Fukuhara H. (1992): Glucose transport in the yeast Kluyveromyces lactis. II. Transcriptional regulation of the glucose transporter gene RAG1. Mol. Gen. Genet. 233, 97-105 doi:10.1007/BF00587566

Coleman S. T., Tseng E., Moye-Rowley W. S. (1997): Saccharomyces cerevisiae basic region-leucine zipper protein regulatory network converge at the ATR1 structural gene. J. Biol. Chem. 272, 23224-23230 doi:10.1074/jbc.272.37.23224

Delahodde A., Delaveau T., Jacq C. (1995): Positive autoregulation of the yeast transcription factor Pdr3p, which is involved in control of drug resistance. Mol. Cell. Biol. 15, 4043-4051

Delaunay A., Pflieger D., Barrault M. B., Vink J., Toledano M. B. (2002): A thiol peroxidase is an $\mathrm{H} 2 \mathrm{O} 2$ receptor and redox transducer in gene activation. Cell 111, 471-481 doi:10.1016/S0092-8674(02)01048-6

Delaveau T., Delahodde A., Carvajal E., Subik J., Jacq C. (1994): PDR3, a new yeast regulatory gene is homologous to PDR1 and controls the multidrug resistance phenomenon. Mol. Gen. Genet. 244, 501-511

doi:10.1007/BF00583901

de Risi J., van den Hazel B., Marc P., Balzi E., Brown P., Jacq C., Goffeau A. (2000): Genome microarray analysis of transcrip- tional activation in multidrug resistance yeast mutants. FEBS Lett. 470, 156-160 doi:10.1016/S0014-5793(00)01294-1

Dujon B., Sherman D., Fischer G. et al. (2004): Genome evolution in yeast. Nature $\mathbf{4 3 0}, 35-44$ doi: $10.1038 /$ nature 02579

Fardeau V., Lelandais G., Oldfield A. et al. (2007): The central role of PDR1 in the foundation of yeast drug resistance. J. Biol. Chem. 282, 5063-5074 doi:10.1074/jbc.M610197200

Harshman K. D., Moye-Rowley W. S., Parker C. S. (1988): Transcriptional activation by the SV40 AP1 recognition element in yeast is mediated by a factor similar to AP-1 that is distinct from GCN4. Cell 53, 321-330 doi:10.1016/0092-8674(88)90393-5

Herrero E., Ros J., Belli G., Cabiscol E. (2008): Redox control and oxidative stress in yeast cells. Biochim. Biophys. Acta 1780, 1217-1235

Heus J. J., Zonneveld B. J. M., Steensma H. Y., van den Berg J. A. (1994): Mutational analysis of centromeric DNA elements of Kluyveromyces lactis and their role in the species specificity of the highly homologous centromeres from K. lactis and Saccharomyces cerevisiae. Mol. Gen. Genet. 243, 325-333 doi:10.1007/BF00301068

Imrichova D., Sarinova M., Cernicka J., Gbelska Y., Subik J. (2005): YAP1-mediated KNQ1 expression in Kluyveromyces lactis. FEMS Yeast Res. 5, 323-329 doi:10.1016/j.femsyr.2004.11.004

Kanazawa S., Driscoll M., Struhl K. (1988): ATR1, a Saccharomyces cerevisiae gene encoding a transmembrane protein required for aminotriazole resistance. Mol. Cell. Biol. 8, 664-673

Kane S. E., Pastan I., Gottesman M. M. (1990): Genetic basis of multidrug resistance of tumor cells. J. Bioenerg. Biomembr. 22, 593-618 doi:10.1007/BF00762963

Katzman D. J., Burnett P. E., Golin J., Mahe Y., Moye-Rowley W. S. (1994): Transcriptional control of the yeast PDR5 gene by the PDR3 gene product. Mol. Cell. Biol. 14, 4653-4661

Kolaczkowska A., Goffeau A. (1999): Regulation of pleiotropic drug resistance in yeast. Drug Resist. Update 2, 403-414 doi:10.1054/drup.1999.0113

Ling V. (1997): Multidrug resistance. Molecular mechanisms and clinical relevance. Cancer Chemother. Pharmacol. 40, S3-8 doi:10.1007/s002800051053

Lucau-Danila A., Lelandais G., Kozovska Z., Tanty V., Delaveau T., Devaux F., Jacq C. (2005): Early expression of yeast genes affected by chemical stress. Mol. Cell. Biol. 25, 1860-1868 doi:10.1128/MCB.25.5.1860-1868.2005

Moye-Rowley W. S. (2003a): Transcriptional control of multidrug resistance in the yeast Saccharomyces. Prog. Nucleic Acids Res. Mol. Biol. 73, 251-279 doi:10.1016/S0079-6603(03)01008-0

Moye-Rowley W. S. (2003b): Regulation of the transcriptional response to oxidative stress in fungi: similarities and differences. Eukaryot. Cell 2, 381-389 doi:10.1128/EC.2.3.381-389.2003

Nguyen D. T., Alarco A. M., Raymond M. (2001): Multiple Yap1p binding sites mediate induction of the yeast major facilitator 